\title{
1. Introduction to the Handbook on the Human Impact of Agriculture
}

\author{
Harvey S. James, Jr.
}

Agriculture includes cultivating land, growing crops and rearing animals for the production of food, fiber and other products. By definition, agriculture necessitates an active effort to change land and living organisms in order to suit human needs. Technically, humans do not need to do 'agriculture' to survive. They could forage or harvest food that grows naturally in the wild. Indeed, for 90 percent of human history, humans practiced hunting and gathering as the primary form of obtaining food and other basic needs (Lee and Daly 1999). However, that changed at about the time human populations expanded and population centers developed. While the causal relationship between population growth and agricultural development remains controversial (Cohen 2009; Larson et al. 2014), the support of large groups of humans requires the active domestication, selective breeding, and nurture of crops and animals (Bocquet-Appel and Bar-Yosef 2008). Thus, agriculture developed approximately 12,000 years ago, most likely in the 'fertile crescent' region of the Middle East that comprises parts of Egypt, Israel, Lebanon, Jordan, Syria and Iraq, in order to accommodate the sedentary and other needs of humans (Breasted 1916; Haviland et al. 2013). Other regions where agriculture developed in support of growing human populations include central China, West Africa, Mesoamerica, central Andes and the New Guinea highlands (Bellwood and Oxenham 2008; Larson et al. 2014).

The development of agriculture resulted in significant advantages to human populations, one of the most important being the means of producing a reliable food supply so that humans could settle and populations could grow. Gignoux et al. (2011: 6044) calculate that 'the invention of agriculture facilitated a fivefold increase in population growth relative to more ancient expansions of hunter-gatherers.' The invention of agriculture is correlated with innovations in ceramics, textiles and metallurgy (Smith et al. 2012), as well as adequate storage technologies (de Saulieu and Testart 2015) and brickmaking (Rosenberg et al. 2020). Some of the earliest known calendars date to the development of agriculture (Fitzsimmons 2016). As populations settled, social and cultural norms changed, too. According to Goodale (2009: 80), the development of agriculture along with supporting technologies 'set the stage for dramatic shifts in human settlement, subsistence strategy, religious and sociocultural beliefs, and technological organization.' For instance, there is evidence suggesting that the first temples and other stone structures originated about the same time as agriculture developed (Curry 2008). Moreover, the egalitarian norms of hunter-gatherer societies evolved into complex social, economic and cultural hierarchal systems and institutions because of the adoption of agriculture. For example, the concept of property 
rights co-evolved along with the development of agriculture, 'because possession of the wealth of farmers - crops, dwellings, and animals - [needed to] be unambiguously demarcated and defended' (Bowles and Choi 2013: 8830).

More than just providing a significant boost to the development of civilization 12,000 years ago, the invention of agriculture then, and the continued innovations in agricultural production throughout history, generate important, if somewhat obvious, benefits to humans. Currently, modern agricultural techniques produce enough food to feed the more than seven billion human inhabitants of the world. Food availability, which the Food and Agriculture Organization of the United Nations (FAO 2008: 1) defines as 'the level of food production, stock levels and net trade' in the world - that is, food available for consumption rather than actual food intake-was 2,908 kilocalories per person per day in 2017, or more than 122 percent of the average calories humans need to consume daily to survive (FAO 2020). ${ }^{1}$ This figure has increased nearly 30 percent since 1961 . Agriculture employs more than 28 percent of the world population. It is a major support for the subsistence of smallholder farmers and other rural populations around the world, contributes to rural economic development, and is an important pathway toward the alleviation of poverty (WBCSD 2008). Agriculture also contributes an average of four percent to world gross domestic product (FAO 2020; data as of 2017). As of 2017, the total world value of agricultural food production was more than $\$ 2$ trillion (FAO 2020; in 2004-06 dollars).

Because there are always tradeoffs, the benefits of agriculture must be weighed against its challenges and the harms it creates. We know, for instance, that agriculture produces a substantial footprint on the environment. Hannah et al. (1994) state that more than three quarters of the habitable portion of the earth has been disturbed by human intervention - that is, where natural habitat is replaced by human activity. Agriculture's claim on the total land area of the world is roughly 37 percent (FAO 2020). Much has been written about the environmental impact of agriculture. While progress has been made in many areas of concern, there are still serious challenges. For example, the United State Geological Survey (USGS 2007: 1) states that 'significant environmental and social issues associated with agricultural production include changes in the hydrologic cycle; introduction of toxic chemicals, nutrients, and pathogens; reduction and alteration of wildlife habitats; and invasive species.' According to Dudley and Alexander (2017: 45), 'agriculture is the largest contributor to biodiversity loss ... by converting natural habitats to intensely managed systems and by releasing pollutants.' Agriculture, particularly the modern versions characterized by intensive cropping and large-scale livestock husbandry practices, has a larger impact on soil erosion and soil degradation than natural processes (Nearing et al. 2017). Approximately one quarter of the total anthropogenic greenhouse gas burden is derived from agriculture, although evidence suggests that 'agriculture is becoming more climate-efficient and has been able to meet higher food demand, whilst reducing emissions relative to total production' (Bennetzen et al. 2016: 764). Finally, chemical use in agriculture contaminates waterways and oceanic water systems and, when nutrient fertilizers enter water systems, results in excessive plant 
and algal growth that depletes oxygen and changes the $\mathrm{pH}$ levels of water (Chislock et al. 2013).

In addition to the environmental effects, a consideration of the human impact of agriculture - that is, the effect that agriculture has on humans-must include both the positive and negative. For example, social inequality has its origins in the development of agriculture. While social inequalities exist in all aspects of society, the invention of agriculture facilitated 'the institutionalization of inequality,' as some segments of society focused on agriculture while others on oversight and wealth accumulation that the surpluses generated by agriculture produced (Price 1995). Acute infectious diseases, such as smallpox and measles, trace their origins to growth of human populations facilitated by the development of agriculture (Kunitz 1994). Agricultural production is also one of the most hazardous occupations (ILO 2020), especially for children and the elderly (Barnes et al. 2020; McLaughlin and Sprufera 2012; Nilsson et al. 2010). There are numerous safety problems that farmers face with chemicals, machinery, interactions with animals, and so forth (Karttunen and Rautiainen 2013; Sprince et al. 2002). There are many other human impacts from agriculture. What are they? This is the focus of the Handbook.

Volumes of scholarly articles have been written about the overall impact of agriculture. Synthesizing what we know, and what we do not know, is therefore challenging. While many handbooks and encyclopedias have summarized issues and ethical debates (for instance Barnhill et al. 2018; Kaplan and Thompson 2019), an exclusive focus on the impact that agriculture and the contemporary food system have on humans is lacking. How does agriculture affect humans? We know agriculture makes it possible for us to provide food and clothing, but what are other ways that agriculture affects humans? While the share of people worldwide employed in agriculture has declined historically, there are many places, especially in developing countries, where human livelihood is tied to or strongly affected by agriculture. Here we would naturally expect agriculture to have a substantial human impact. But even in places where employment within the agricultural system is relatively small, what is agriculture's human impact? Is it minor or is its reach far and wide?

The purpose of this Handbook is to synthesize and document key issues and concerns relating to agriculture's human impact. The premise underlying this work is that the impact is pervasive. In this context, agriculture refers to all aspects of or relating to the production of food and fiber within the agrifood value chain, including farmers and laborers growing crops and raising livestock to businesses supplying inputs for these operations to processors transforming plants and animals into intermediate and finished food, beverage and clothing products that are purchased by consumers. Human impact refers to the influence or effect agriculture has on farmers, non-farmers, communities and society as a whole. While not intended to be an exhaustive treatment, the collection of chapters in this Handbook covers a wide range of relevant and important issues. 


\section{OVERVIEW OF HANDBOOK CONTENT}

In addition to the Introduction, this Handbook consists of 20 chapters divided into four parts. The first three parts focus primarily on farmer and farm producers, while the fourth part considers impacts on others.

\section{Part I: Impacts of Agricultural Institutions and Organizations}

The first part consists of four chapters. Its focus is on how the institutions and organizations of the agrifood industry, and their subparts, affect farmer well-being.

MacDonald reviews the evidence of consolidation within the agrifood industry and its effects on farmers, focusing on farm household incomes, wages and employment for hired farm labor, health and safety of farmers and farmworkers, and autonomy of farm operators. His analysis focuses primarily on the agricultural industry in North America, but MacDonald also comments on consolidation impacts in developing countries. While considerable evidence exists of consolidation effects on agricultural productivity, prices and the environment, data limitations make it difficult to draw definitive conclusions about effects on farmers and farmer well-being. MacDonald's commentary suggests that more attention is needed on evaluating the human impacts of consolidation.

Constance and Rainey comment on the effect that consolidation and contracting in the poultry industry have on farmer well-being, with a particular emphasis on the 'tournament' system used by poultry integrators to rank and reward contract broiler growers. While integrators see the tournament as an acceptable compensation device that incentivizes grower performance, growers view the contract as a way of facilitating opportunistic behavior by integrators. Constance and Rainey provide evidence of farmer concerns. They conclude that policymakers need to be not only more attentive to the perspective of farmers but also less susceptible to the influence of corporate interests who seek to minimize genuine agrarian reform efforts.

Stuart shows how farm input industries shape farmer decisions in ways that are harmful to the environment and farmers. Using the fertilizer industry as a case study, Stuart argues that oligopolistic conditions in the fertilizer and seed industry allow companies to exert considerable control over commercial corn farmers' access to and information about products and farm practices. As a result, farmers are influenced to utilize an excessive amount of fertilizer that contributes to surface and ground water pollution and leads to other negative impacts to farmers, ecosystems and society. Stuart concludes that regulations need to reorient seed and fertilizer incentives to consider more carefully the interests of farmers and the environment.

Forney and Sutherland consider how agrarianism, materiality and views about the 'good farmer' affect farmers' self-identification. They focus particularly on issues of farm succession, family labor, gender and farming as a lifestyle. Forney and Sutherland find that positive images of farming need to be contrasted with the risks and pressures created by institutional and societal influences. They conclude that the lens by which scholars and others view and evaluate farmers needs to be broadened 
to better contextualize farming within the realities of farming as a practice and farming as an identity.

\section{Part II: Impacts of Agricultural Science and Technology}

The second part consists of four chapters. The focus here is on the application of science and technologies within an agricultural context, such as biotechnology and mechanization. Because of the importance of emerging digital technologies in agriculture, two chapters address complementary perspectives about the topic.

Glenna and Ransom examine how the genetic modification of crops and animals has affected farmers. They also highlight findings from impact assessments of genetically modified organisms (GMOs) and identify limitations of these studies. Glenna and Ransom argue that impact assessments have not been helpful to farmers, in part because they do not adequately reflect the social context of farmers, rural communities, and the agrifood system as a whole. Future GMO impact assessments should focus on anticipated outcomes, as well as institutional and policymaker responsiveness to farmer feedback. Glenna and Ransom also argue that GMO technologies need to do more to deliver on their promises of improving the well-being of all farmers.

Ait Sidhoum, Vrachioli and Sauer study the human impact of agricultural mechanization on farmers and farm laborers, focusing particularly on labor employment and farmers' mobility, such as labor displacement tendencies. They find that the overall effect of mechanization on labor demand and farmer well-being is mixed and depends on the specific technology adopted and the dynamics of existing labor markets and policy environments. The authors conclude that policies need to carefully recognize and balance potential conflicts of new technologies on farmer livelihoods, gender inequality, community development and environmental sustainability.

Bronson, Rotz and D'Alessandro consider the implications on farmer decision-making of technologies relating to large datasets and artificial intelligent machines on what they term the 'smart farm.' By focusing on cases relating to private sector agricultural data analytics and public computer science research into machine intelligence, the authors show that decisions about which data to collect and how to use big data benefit existing powerful food system actors, including large-scale farmers and the agribusinesses supplying them. Such technologies can also be deleterious to smaller farmers and alternative agricultural producers. Bronson et al. conclude that the bias these technologies have toward larger farms creates challenges for overcoming social and environmental problems existing within the agrifood sector.

Duncan, Abdulai and Fraser analyze the effect of digital technologies, such as sensors, robotics, and big data analytics platforms, on farmers and their ability to produce food sustainably. Such technologies present opportunities to improve the sustainably of food production, but claims about their effectiveness are also overstated. The authors also contrast the potential impact these technologies have on production systems in both the Global North and South, focusing specifically on climate change and the consequences of digital technologies and agricultural knowledge production. Duncan et al. argue that there are varied effects of the 'digital revolution' 
on farmers and society. They conclude that more work is needed to refine discourses around sustainable agriculture at its broadest level, especially in the context of continued developments of digital technologies.

\section{Part III: Impacts of Agriculture on Smallholder Farmers and Farm Laborers}

The third part consists of seven chapters. This is the largest section of the Handbook, because of the critical ways agriculture affects the well-being of smallholder farmers, especially in developing countries.

Snyder explores the impact of 'modern' agriculture on smallholder farmer livelihoods in the Global South, where 'modern' means farming viewed as a business and smallholder farmers utilizing hybrid seeds, chemical inputs and planting practices consistent with conventional agricultural techniques in the Global North. Snyder argues that most farmers pursue a mix of strategies categorized as 'modern' and 'traditional.' While there have been analyses of agricultural production in the Global South, they often do not reflect the context of agricultural production in developing countries. To this end, she reviews existing studies as well as primary research carried out in countries in sub-Saharan Africa to show that 'modern' agricultural practices can improve farmer livelihoods, but they do so by increasing economic and other risks to them as well. Snyder concludes that appropriate institutional and infrastructural support is needed to ensure that the benefits to farmers consistently outweigh the problems created by 'modern' agriculture.

Kalfagianni identifies important effects of private standards applied to agricultural production on smallholder farmers. She states that the extent to which private standards provide benefits depends on a variety of factors, such as the design of the standards, the broader political economy of food, and the presence of supporting local institutions. Kalfagianni argues that smallholder well-being is best served when private standards incorporate or recognize smallholder needs, wants and capabilities, including material, social, political and environmental aspects of well-being. She concludes that efforts to understand smallholder well-being from their perspective is a crucial step for the functioning of private standards and for future academic research.

Lyon reviews the effects of fair trade programs on smallholder farmers. She shows that the impacts of fair trade on smallholders are complex, multilayered and often contradictory. For this reason, it is important to understand how and why the geographic, economic, political and cultural context of agriculture shapes fair trade's impacts and smallholder participation in these programs. Lyon concludes that future research should focus on how to better measure fair trade impacts and to explore the ways in which the human impacts of fair trade are shaped by local realities in order to identify the most effective practices and policies for improving smallholder livelihoods and well-being.

Kuehne examines the effect of pesticide use on farmers in India using a systems viewpoint. In particular, Kuehne describes the factors influencing their pesticide safety behavior and the relationships between them. According to Kuehne, social, 
cultural and economic disadvantages are at the root of why pesticide practices and safety behavior are poor in India. He argues that the costs to human health from these poor practices occur within a complex system of social, economic, personal and cultural influences. Therefore, interventions aimed at reducing their negative impacts will need to recognize and respond to the complexity of influences on Indian farmers' pesticide practices. Kuehne concludes that while some of these influences are unique to India, the factors influencing farmers' pesticide safety are likely to be experienced by most smallholder farmers of developing countries.

Giwa Daramola and James show how agriculture provides an important social protection function and safety net for smallholder farmers and others vulnerable to rural poverty. While agriculture contributes to the kind of economic growth that has the potential to lift people out of poverty, agriculture can do much more to improve the livelihoods of farmers and others affected by poverty, especially in developing countries. Giwa Daramola and James argue that agriculture's role in pro-poor growth is dependent on how agriculture intersects with social protection programs and policies to ensure that the poorest people are not left behind. To this end, the authors explore social protection and its interaction with agriculture. They also present cases exploring the interaction among agriculture, policy and agriculture's social protection function and consider challenges that impede agriculture's social protection functions.

Binford and McLaughlin summarize the effects that two temporary foreign agricultural worker programs have on migrant farmers in North America: Canada's Seasonal Agricultural Worker Program and the United States' H-2A Program. According to Binford and McLaughlin, the Canadian program is recognized as a model, while the U.S. program is routinely criticized. The authors argue that the two programs are quite similar. Both tie migrant workers to assigned employers for the duration of the contract. They also allow employers to control workers' present and future employment opportunities, housing conditions, and other aspects of their lives. The implication is that migrant workers do not have any meaningful collective means of resisting potentially exploitive working conditions. Of particular concern, according to the authors, is the lack of a pathway for temporary migrant workers to obtain permanent residency in these countries.

Laforge and Levkoe review impacts that agroecology training has on smallholder farmers, particularly their ability to reclaim agency and control of food production. The authors observe that while there has been an increase in farmer training programs focusing on agroecological farming practices, many persons completing the programs do not become farmers but rather embark on other career paths. This does not negate the value of the programs, because graduates who do not farm might become advocates for appropriate change in the agrifood system. Laforge and Levkoe conclude that farmer training programs should provide a better foundation in food sovereignty in order to address fundamental social and environmental injustices that are at the core of modern agrifood systems. 


\section{Part IV: Broader Impacts of Agriculture on Society}

The fourth part consists of five chapters. The focus of this section is on agriculture's impact beyond the agrifood system and into broader aspects of society.

Galt and Asprooth provide an extensive review of studies examining the direct and indirect human health effects of agricultural chemical use. They show that common diseases, such as diabetes, obesity, asthma, cancer, heart disease, and a range of reproductive and fetal harms, are caused or exacerbated by agrochemicals. They also show that the use of agrochemicals has a far-reaching impact on humans as well as on ecological systems. Galt and Asprooth conclude by arguing that transitioning to a post-agrochemical agrifood system is necessary to achieve an equitable and sustainable future.

Christensen considers the important role that agricultural activity and rural living have on the cultural values of society across the globe. He shows, for instance, that autonomy, frugality and hard work, which have been recognized as a foundation of farm and rural life, have often influenced the broader values adopted by humans and reflected in society. Christensen concludes that there is a "nostalgic sense of the fondness' by many people in what farmers do and, therefore, farmers continue to be positive models on society.

Ebel, Menalled, Ahmed, Gingrich, Baldinelli and Félix show that widespread monocropping and the resulting biodiversity loss characteristic of modern agriculture have created substantial consequences on society. In particular, they describe adverse effects on culture, diets, gender issues, food security and resilience of rural communities, among others. Ebel et al. argue that there is an important feedback loop that scholars and policymakers need to understand: agrobiodiversity loss is caused by societal conditions but also generates impacts on society. They conclude that a systemic approach is needed to identifying and implementing solutions for reversing this negative spiral.

James reviews the ethical implications of agricultural production. According to James, ethical issues arise when the interests, values, rights or obligations of humans conflict. Such conflicts can be found in all dimensions of life. However, James suggests there are distinctive aspects of agriculture that have a direct ethical impact on humans. After exploring these issues, James concludes that it is important to assess ethical challenges, because only then can efforts be developed to resolve their underlying conflicts.

Zepeda identifies important criticisms of the contemporary food system, particularly its link to unhealthy eating. Fortunately, the agrifood system is evolving to have different approaches or alternatives for consumers who are appropriately motivated to eat healthy. To this end, Zepeda considers four alternatives: self-provisioning, local food, organic food and activism. She notes that most alternatives are accessible only to consumers who have a sufficient income. Zepeda concludes that while consumers are responsible for what they eat, national policies need to encourage healthy eating rather than support for a system that promotes 'cheap, unhealthy food from a handful of companies.' 


\section{FINAL COMMENTS}

This Handbook advances our understanding of agriculture's human impact by presenting, in a dedicated collection of chapters, scholarship from a variety of experts covering a range of relevant topics. While there is a lot we know about how agriculture affects humans, assessing this knowledge is an important step in determining where research needs to go in order to identify concerns and develop appropriate scholarly and policy responses.

\section{NOTE}

1. Food availability is only one component of food security. Just because food is available does not mean it is accessible, nutritionally adequate or consistently available over an extended period of time, which are other dimensions of food security (see FAO 2008).

\section{REFERENCES}

Barnes, K.L., Rudolphi, J., Kivirist, L. and Bendixsen, C.G. 2020. Childhood agricultural injury prevention among organic farmer mothers. Journal of Agromedicine, DOI: 10.1080 /1059924X.2020.1744495.

Barnhill, A., Budolfson, M. and Doggett, T. 2018. The Oxford Handbook of Food Ethics. Oxford, UK: Oxford University Press.

Bellwood, P. and Oxenham, M. 2008. The expansions of farming societies and the role of the Neolithic demographic transition. In J-.P. Bocquet-Appel and O. Bar-Yosef, eds., The Neolithic Demographic Transition and Its Consequences, 13-34. Dordrecht: Springer.

Bennetzen, E.H., Smith, P. and Porter, J.R. 2016. Decoupling of greenhouse gas emissions from global agricultural production: 1970-2050. Global Change Biology 22(2): 763-81.

Bocquet-Appel, J.-P. and Bar-Yosef, O. 2008. The Neolithic Demographic Transition and Its Consequences. Dordrecht: Springer.

Bowles, S. and Choi, J.-K. 2013. Coevolution of farming and private property during the early Holocene. PNAS 110(22): 8830-5.

Breasted, J.H. 1916. Ancient Times: A History of the Early World. Boston, MA: Ginn.

Chislock, M.F., Doster, E., Zitomer, R.A. and Wilson, A.E. 2013. Eutrophication: causes, consequences, and controls in aquatic ecosystems. Nature Education Knowledge 4(4): 10.

Cohen, M.H. 2009. Introduction: rethinking the origins of agriculture. Current Anthropology 50(5): 591-5.

Curry, A. 2008. Gobekli Tepe: the world's first temple? Smithsonian Magazine, November, https://www.smithsonianmag.com/history/gobekli-tepe-the-worlds-first-temple-83613665/ (accessed 7 September 2020).

de Saulieu, G. and Testart, A. 2015. Innovations, food storage and the origins of agriculture. Environmental Archeology 20(4): 314-20.

Dudley, N. and Alexander, S. 2017. Agriculture and biodiversity: a review. Journal of Biodiversity 18(2-3): 45-9.

Fitzsimmons, H. 2016. The world's oldest observatory? How Aboriginal astronomy provides clues to ancient life. ABC News, 12 October, https://www.abc.net.au/news/2016-10 -12/aboriginal-astronomy-provides-clues-to-ancient-life/7925024 (accessed 7 September 2020). 
FAO [Food and Agriculture Organization]. 2008. An introduction to the basic concepts of food security, http://www.fao.org/3/a-al936e.pdf (accessed 9 September 2020).

FAO [Food and Agriculture Organization]. 2020. FAOSTAT: World, http://www.fao.org/ faostat/en/\#country (accessed 9 September 2020).

Gignoux, C.R., Henn, B.M. and Mountain, J.L. 2011. Rapid, global demographic expansions after the origins of agriculture. PNAS 108(15): 6044-9.

Goodale, N.B. 2009. Convergence in the Neolithic: human population growth at the dawn of agriculture, PhD dissertation. Pullman, WA: Department of Anthropology, Washington State University.

Hannah, L., Lohse, D., Hutchinson, C., Carr, L.L. and Lankarani, A. 1994. A preliminary inventory of human disturbance of world ecosystems. Ambio 23: 246-50.

Haviland, W.A., Prins, H.E.L., Walrath, D. and McBride, B. 2013. The Essence of Anthropology, 3rd edn. Belmont, CA: Wadsworth.

ILO [International Labor Organization]. 2020. Agriculture: a hazardous work, https://www.ilo .org/safework/areasofwork/hazardous-work/WCMS 110188/lang--en/index.htm (accessed 22 October 2020).

Kaplan, D. and Thompson, P.B. 2019. Encyclopedia of Food and Agricultural Ethics, 2nd edn. Dordrecht: Springer.

Karttunen, J.P. and Rautiainen, R.H. 2013. Occupational injury and disease incidence and risk factors in Finnish agriculture based on 5-year insurance records. Journal of Agromedicine 18(1): 50-64.

Kunitz, S.F. 1994. Disease and the destruction of indigenous populations. In T. Ingold, ed., Companion Encyclopedia of Anthropology: Humanity, Culture and Social Life, 297-325. London: Routledge.

Larson, G., Piperno, D.R., Allaby, R.G., Purugganan, M.D., Andersson, L., ... Fuller, D.Q. 2014. Current perspectives and the future of domestication studies. PNAS 111(17): 6139-46.

Lee, R.B. and Daly, R. 1999. The Cambridge Encyclopedia of Hunters and Gatherers. Cambridge: Cambridge University Press.

McLaughlin, A.C. and Sprufera, J.F. 2012. Aging farmers are at high risk for injuries and fatalities: how human-factors research and application can help. North Carolina Medical Journal 72(6): 481-3.

Nearing, M.A., Xie, Y., Liu, B. and Ye, Y. 2017. Natural and anthropogenic rates of soil erosion. International Soil and Water Conservation Research 5(2): 77-84.

Nilsson, K., Pinzke, S. and Lundqvist, P. 2010. Occupational injuries to senior farmers in Sweden. Journal of Agricultural Safety and Health 16(1): 19-29.

Price T.D. 1995. Social inequality at the origins of agriculture. In T.D. Price and G.M. Feinman, eds., Foundations of Social Inequality: Fundamental Issues in Archaeology, 129-51. Boston, MA: Springer.

Rosenberg, D., Love, S., Hubbard, E. and Klimscha, F. 2020. 7,200-year-old constructions and mudbrick technology: the evidence from Tel Tsaf, Jordan Valley, Israel. Plos ONE 15(1): e0227288.

Smith, B.G., Van De Mieroop, M., von Glahn, R. and Lane, K. 2012. Crossroads and Cultures: A History of the World's Peoples. Boston, MA: Bedford/St. Martin's.

Sprince, N.L., Park, H., Zwerling, C., Lynch, C.F., Whitten, P.A., ... Alavanja, C.R. 2002. Risk factors for machinery-related injury among Iowa farmers: a case-control study nested in the agricultural health study. International Journal of Occupational and Environmental Health 8(4): 332-8.

USGS [U.S. Geological Survey]. 2007. Investigating the environmental effects of agriculture practices on natural resources, https://pubs.usgs.gov/fs/2007/3001/pdf/508FS2007_3001 .pdf (accessed 10 September 2020). 
WBCSD [World Business Council for Sustainable Development]. 2008. Agricultural ecosystems: facts and trends, http://docs.wbcsd.org/2008/07/Agricultural_Ecosystems.pdf (accessed 10 September 2020). 